\title{
Identification and resistance profile of gram positive bacteria from aquatic
}

\section{environment}

\author{
Identificação e perfil de resistência de bactéria gram-positivas do ambiente aquático \\ Identificación y perfil de resistencia a bacterias gramo positivas en el ambiente acuático
}

Thais Reis Oliveira

ORCID: https://orcid.org/0000-0002-4979-8653 Federal University of Goiás, Brazil E-mail: thaisreisoliveira@hotmail.com

Raylane Pereira Gomes ORCID: https://orcid.org/0000-0001-8495-1361 Federal University of Goiás, Brazil E-mail: raylanepgomes@gmail.com

Ariadne Bernardes Rodrigues ORCID: https://orcid.org/0000-0002-0325-1409 Federal University of Goiás, Brazil E-mail: ariadne.rodrigues99@gmail.com

Leandro Martins Ferreira

ORCID: https://orcid.org/0000-0002-4312-6215 Federal University of Goiás, Brazil E-mail: leandrolemf@gmail.com

Aline Rodrigues Gama

ORCID: https://orcid.org/0000-0003-2167-3872 Alfredo Nasser University Center, Brazil

E-mail: alinerodriguesgama15@gmail.com José Daniel Gonçalves Vieira ORCID: https://orcid.org/0000-0001-5434-4915 Federal University of Goiás, Brazil E-mail: jvieira@ufg.br

Marcos Rassi Fernandes

ORCID: https://orcid.org/0000-0001-8078-528X Federal University of Goiás, Brazil

E-mail: marcosombro@ufg.br

Lilian Carla Carneiro

ORCID: https://orcid.org/0000-0003-4067-1506 Federal University of Goiás, Brazil E-mail: carlacarneirolilian@gmail.com

\begin{abstract}
The Meia Ponte River - Goiás/Brazil, is responsible for benefiting about 2 million people in Goiás State. However, the increase in pollution with the disposal of sewage, chemicals and drug remains have contributed to the increase in bacterial resistance and the exchange of resistance genes. The objective of this study was to isolate, identify and analyze the resistance profile of gram-positive bacteria present in raw water and sediment of the Meia Ponte River Goiás. The samples were collected from four sampling points and two collections were carried out, one in the dry season and the other in the rainy season. The isolated bacteria were identificated, then the antibiogram was performed. A total of 75 strains were isolated, $72.0 \%$ (54/75) of Streptococcus spp., 12.0\% (9/75) of Staphylococcus spp., 9.3\% (7/75) of Bacillus spp. and 6.7\% (5/75) of Enterococcus spp. Furthermore, 52.0\% (39/75) of the isolated strains were from raw water and $48.0 \%$ (36/75) were isolated from the sediment. Among the samples, strains of Staphylococcus spp. and Bacillus spp. showed greater resistance to antimicrobials, on the other hand, Enterococcus spp. showed less resistance. Some strains of Bacillus spp. and Streptococcus spp. presented multidrug resistant, Staphylococcus spp. showed multidrug resistant and some pan-drug resistant. In the correlation of Spearman Staphylococcus spp. and Streptococcus spp. isolated, were the ones that presented the most significant correlations ( $<<0.05)$. Thus, the study shows the importance of ascertaining the resistance profile of this group of bacteria that aquatic environment.
\end{abstract}

Keywords: Correlation; Drugs; Pan-drug; Resistance genes.

\section{Resumo}

O Rio Meia Ponte - Goiás/Brasil, é responsável por beneficiar cerca de 2 milhões de pessoas no Estado de Goiás. No entanto, o aumento da poluição com o descarte de esgoto, produtos químicos e restos de drogas têm contribuído para o 
aumento da resistência bacteriana e a troca de genes de resistência. O objetivo deste estudo foi isolar, identificar e analisar o perfil de resistência das bactérias gram-positivas presentes na água bruta e sedimento do Rio Meia Ponte Goiás. As coletas foram realizadas em quatro pontos de amostragem e foram realizadas duas coletas, uma no período da seca e outra no período da chuva. As bactérias isoladas foram identificadas e, em seguida, realizado o antibiograma. Um total de 75 cepas foram isoladas, 72,0\% (54/75) de Streptococcus spp., 12,0\% (9/75) de Staphylococcus spp., 9,3\% (7/75) de Bacillus spp. e 6,7\% (5/75) de Enterococcus spp. Além disso, 52,0\% (39/75) das cepas isoladas foram provenientes de água bruta e 48,0\% (36/75) foram isoladas do sedimento. Dentre as amostras, cepas de Staphylococcus spp. e Bacillus spp. apresentou maior resistência aos antimicrobianos, por outro lado, Enterococcus spp. mostrou menos resistência. Algumas cepas de Bacillus spp. e Streptococcus spp. apresentou multirresistência, Staphylococcus spp. mostrou multirresistência e alguns pan-resistências. Na correlação de Spearman Staphylococcus spp. e Streptococcus spp. isolados, foram os que apresentaram as correlações mais significativas (p $<0,05)$. Dessa forma, o estudo mostra a importância de se conhecer o perfil de resistência desse grupo de bactérias nesse ambiente aquático.

Palavras-chave: Correlação; Drogas; Genes de resistência; Pan-resistências.

\section{Resumen}

El río Meia Ponte - Goiás/Brasil, es responsable de beneficiar a cerca de 2 millones de personas en el estado de Goiás. Sin embargo, el aumento de la contaminación con eliminación de aguas residuales, productos químicos y restos de medicamentos ha contribuido al aumento de resistencia bacteriana y intercambio de genes de resistencia. El objetivo de este estudio fue aislar, identificar y analizar el perfil de resistencia de bacterias grampositivas presentes en aguas crudas y sedimentos del río Meia Ponte - Goiás. Las muestras se recolectaron de cuatro puntos de muestreo y se realizaron dos recolecciones, una en época seca y otra en época de lluvias. Se identificaron las bacterias aisladas, luego se realizó el antibiograma. Se aislaron un total de 75 cepas, 72,0\% (54/75) de Streptococcus spp., 12,0\% (9/75) de Staphylococcus spp., 9,3\% (7/75) de Bacillus spp. y 6,7\% (5/75) de Enterococcus spp. Además, el 52,0\% (39/75) de las cepas aisladas procedían de agua cruda y el 48,0\% (36/75) se aislaron del sedimento. Entre las muestras, cepas de Staphylococcus spp. y Bacillus spp. mostró mayor resistencia a los antimicrobianos, por otro lado, Enterococcus spp. mostró menos resistencia. Algunas cepas de Bacillus spp. y Streptococcus spp. presentó resistentes a múltiples fármacos, Staphylococcus spp. se mostró multirresistente y algunos panresistentes. En la correlación de Spearman Staphylococcus spp. y Streptococcus spp. aisladas, fueron que presentaron las correlaciones más significativas (p $<0.05)$. Así, el estudio muestra la importancia de conocer el perfil de resistencia de este grupo de bacterias que el medio acuático.

Palabras clave: Correlación; Fármacos; Genes de resistencia; Panresistentes.

\section{Introduction}

In the mid-1940s, the fight against infections began using antibiotics and over the years this drug has been applied in agricultural, industrial and veterinary sectors. The indiscriminate use of antimicrobials contributes to the increase in resistant bacteria, including the dissemination of their resistance genes in the environment (Shao et al., 2018).

Sewage discharged into rivers is associated with an increase in resistant bacteria in the environment, due to the fact that these medications are not fully metabolized by the body, leaving traces present in both urine and feces of living beings. Other factors that also contribute to the topic addressed are the medicines applied in agriculture that end up contaminating soils and rivers, as well as industries despising them in the aquatic environment (Gogoi et al., 2018; RuizAguirre et al., 2017). In addition to these reported compounds, numerous others also influence the increase in environmental contamination, being called emerging contaminants (ECs). Thus, ECs have caused environmental impacts, increased bacterial resistance and generated public health problems (Gogoi et al., 2018; Mohapatra \& Kirpalani, 2019).

The increase in antibiotic resistance genes (ARGs) in environmental bacteria is associated with selective pressure of antibiotics in water, together with the acquisition of resistance genes present in the environment from animals and/or humans, causing the exchange of genetic material in aquatic sites (Maruzani et al., 2020; Wang et al., 2020).

The aquatic environment is considered the largest disseminator and deposit of ARGs, this is due to pollution and the "stress" that occurs on the bacteria in the presence of antibiotics in the environment (Amarasiri et al., 2019; Dang et al., 2017). The ARGs sharing occurs through mobile genes as conjugated plasmids and transposons, integron, among others; 
thus facilitating horizontal transfer and exchange of genes among bacteria (Dang et al., 2017; Sobisch et al., 2019).

The presence of resistant gram-positive bacteria in aquatic sites is of concern, as some are signs of fecal contamination, such as Enterococcus. Others are pathogenic to humans, such as Staphylococcus (Karkman et al., 2018), in which the acquisition of resistance genes makes it difficult to find effective antimicrobials against infections (Rahmani et al., 2020). Other gram-positive bacteria considered important are Streptococcus spp., which are responsible for being pathogenic and for developing severe infections in humans (Zhang et al., 2018), and Bacillus spp. that are known for spore formation, resistance to environmental changes and can cause food poisoning in the population (Ruiz-Aguirre et al., 2017).

The Meia Ponte River is one of the main water resources in the Goiás State - Brazil, being responsible for benefiting about 2 million people from Goiás and contributing to agriculture, livestock, water supply, recreation, among others. With the urbanization and with one of the tributaries running through the metropolitan region of Goiânia city, it caused an increase of pollution, interfering with its water quality (Bailão et al., 2020; Coelho et al., 2021).

Because it is an essential condition of the water supply network of Goiás and knowing that the presence of resistant bacteria that location can harm the health of the population, it becomes necessary to research and investigate the presence of these microorganisms in this aquatic environment. Thus, the aim of the study was to isolate, identify and verify the resistance profile of gram-positive bacteria taken from raw water and sediment from the aquatic environment.

\section{Methodology}

This study deals with an experimental research (Köche, 2016; Pereira et al., 2018) for its methodological basement.

\subsection{Study area and sample collection}

The collection of raw water and sediment samples were made in four sample points following the basin of the Meia

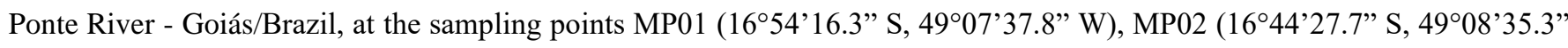

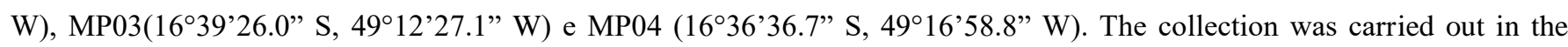
period of December 2018, characterized as the beginning of the rainy season and in the period of September 2019, characterized as dry period.

The collection of raw water and sediment followed the National Guide for Collection and Preservation of Samples (Brandão et al., 2011), $100 \mathrm{~mL}$ of raw water and $20 \mathrm{~g}$ of sediment from each sampling point were collected in sterile flasks, in addition to recording the water temperature with the aid of a thermometer at the time of each collection. After collection, the samples were stored and refrigerated on ice (temperature between $2{ }^{\circ} \mathrm{C}$ to $8{ }^{\circ} \mathrm{C}$ ), and these samples were to be processed within a maximum of 24 hours after collection.

\subsection{Bacterial count and isolation}

The $20 \mathrm{~g}$ of sediment samples from each collection point were added in $0.5 \%$ Tween solution ( $200 \mathrm{~mL}$ of solution) and incubated in a shaker (BIOCOMPARE®) for 2 hours at $30{ }^{\circ} \mathrm{C}$, later, $200 \mu \mathrm{L}$ of this solution was seeded in petri dishes using the scanning technique and incubated for 48 hours at $37^{\circ} \mathrm{C}$. The raw water samples were homogenized, $200 \mu \mathrm{L}$ of these samples were seeded in petri dishes using the scanning technique and the plates were incubated for 48 hours in a bacteriological incubator at $37^{\circ} \mathrm{C}$ (APHA, 2017).

The petri dishes had specific culture media for isolation and quantification of gram-positive bacteria, using the Azide Dextrose Broth Agar (ADBA) and Enterococcus Confirmatory Agar (ECA), both from the company HIMEDIA®. The bacterial isolation and quantification process followed the protocol (APHA, 2017), being necessary to quantify the Colony Forming Units (CFU) present on the plates, select the morpho-colonial characteristics of each culture medium used, following 
the respective leaflets of the HIMEDIA $®$ to carry out the isolations of these bacteria. The preservation of pure colonies, in turn, were preserved in $2 \mathrm{~mL}$ cryogenic tubes, containing $20 \%$ glycerol in medium BHI (Brain Heart Infusion) BD $®$ at $-4^{\circ} \mathrm{C}$.

\subsection{Bacterial identification}

The identification followed the Manual of Clinical Microbiology for the Control of Infection Related to Health Care (ANVISA, 2013). To phenotypic identification was used tests: Gram stain, catalase test, verification of spore and filament production, motility were performed, hydrogen sulfide $(\mathrm{H} 2 \mathrm{~S})$ production, indole production, $5 \% \mathrm{NaCl}$ tolerance test, esculin bile test, blood agar growth and hemolysis and DNAse test.

\subsection{Antibiogram}

The antimicrobial susceptibility test of disk diffusion method followed the National Sanitary Surveillance Agency (ANVISA, 2005), was done the suspension of the bacterial strain in $0.85 \%$ saline solution, adjusting with the turbidity on the 0.5 McFarland scale. With the aid of a swab, the bacterial suspension was evenly seeded in a Petri dish, containing MuellerHinton agar. Then, a set of antimicrobial discs was distributed over the agar surface. The plates were incubated in a bacteriological incubator at $30^{\circ} \mathrm{C}$ for 24 hours and then the inhibition halos were read.

The antibiotics used during the experiment were: Ampicillin (AMP $10 \mu \mathrm{g}$ ), Azithromycin (AZI $15 \mu \mathrm{g}$ ), Cefoxitin (CFO $30 \mu \mathrm{g}$ ), Ciprofloxacin (CIP $5 \mu \mathrm{g}$ ), Clindamycin (CLI $2 \mu \mathrm{g}$ ), Chloramphenicol (CLO $30 \mu \mathrm{g}$ ), Erythromycin (ERI $15 \mu \mathrm{g}$ ), Gentamicin (GEN $10 \mu \mathrm{g}$ ), Linezolid (LNZ $30 \mu \mathrm{g}$ ), Oxacillin (OXA $1 \mu \mathrm{g}$ ), Penicillin G (PEN $10 \mu \mathrm{g}$ ), Rifampicin (RIF 5), Sulfazotrim Sultamethoxazole/Trimethoprim (SUT 25), Tetracycline (TET $30 \mu \mathrm{g}$ ) e Vancomycin (VAN $30 \mu \mathrm{g}$ ), being both from polisensidisc 15 DME gram positive (DME®). The interpretation of the results followed the (CLSI, 2019) and (Yusuf et al., 2018). Following (Asma et al., 2019) and modifications, it was considered Multi-Drug Resistant (MDR) bacteria resistant to 3 or more classes of antibiotics tested and Pan-Drug Resistant (PDR) bacteria resistant to all tested antibiotics.

\subsection{Statistic}

For data tabulation and descriptive statistics, Microsoft Excel 2016 was used. To verify the association and correlation, Spearman's correlation test was used in STATISTICA software 7.0 version (StatSof@) (StatSoft I, 2012).

\section{Results}

The The water temperature during the collections in the dry and rainy period of all sampling points had an average of $23.9^{\circ} \mathrm{C}$, being an elevated temperature compared to the established criterion of $<20^{\circ} \mathrm{C}$ (WHO, 2017).

Table 1 shows the results of counting the CFU of the culture media from the two collections.

Table 1. Bacterial quantification in culture media with samples of raw water and sediment in an aquatic environment from the Meia Ponte river, Goiás State, Brazil.

\begin{tabular}{ccccccc}
\hline \multirow{2}{*}{ Collection and Period } & \multirow{2}{*}{ Sample } & \multirow{2}{*}{ Culture Mediums } & \multicolumn{3}{c}{ Sample Points (CFU/200 $\boldsymbol{\mu L}$ ) } \\
\cline { 4 - 6 } Collection 1 - rainy season & Raw water & ADBA & 4 & MP2 & MP3 & MP4 \\
& Sediment & ADBA & 4 & 15 & 80 & 1 \\
& Raw water & ECA & 1 & 7 & $\mathbf{3 5 3}$ & 61 \\
& Sediment & ECA & 1 & 51 & 31 & 1 \\
Collection 2 - dry period & Raw water & ADBA & 1 & $\mathbf{2 3 8}$ & $\mathbf{3 5 3}$ & 1 \\
& Sediment & ADBA & 0 & 5 & 0 & 0 \\
& Raw water & ECA & 0 & 69 & 16 & 0 \\
& Sediment & ECA & 0 & 2 & 0 & 4 \\
\hline
\end{tabular}

ADBA: Azide Dextrose Broth Agar; ECA: Enterococcus Confirmatory Agar; MP1: collection point 1; MP2: collection point 2; MP3: collection point 3; MP4: collection point 4. Source: Authors. 
In Table 1. it is possible to observe that at some points there was a greater amount of CFU.

With the aid of culture media, it was possible to isolate a total of 75 strains of bacteria with samples of raw water $52.0 \%(39 / 75)$ and sediment $48.0 \%$ (36/75), being that the ADBA medium isolated $48.9 \%(22 / 45)$ of the raw water and 51.1\% $(23 / 45)$ of the sediment, in the medium ECA isolated $56.7 \%(17 / 30)$ of the raw water and $43.3 \%(13 / 30)$ isolated of the sediment.

Comparing the identified bacteria with the total of isolates that each culture medium provided, ADBA medium isolated 82.2\% (37/45) of Streptococcus spp., 8.8\% (4/45) of Enterococcus spp., 6.6\% (3/45) of Staphylococcus spp. and 2.2\% (1/45) of Bacillus spp. The ECA medium isolated $56.7 \%$ (17/30) of Streptococcus spp., 20.0\% (6/30) of Staphylococcus spp., 20.0\% (6/30) of Bacillus spp. and 3.3\% (1/30) of Enterococcus spp. Still following this information, the total number of isolated strains were Streptococcus spp. $72.0 \%$ (54/75), Staphylococcus spp. 12.0\% (9/75), Bacillus spp. 9.3\% (7/75) and Enterococcus spp. 6.7\% (5/75).

The data antimicrobial susceptibility testing are shown in Table 2. 


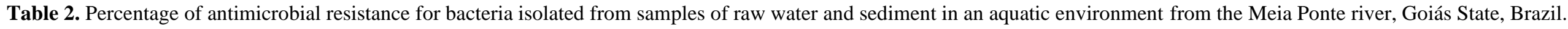

\begin{tabular}{|c|c|c|c|c|c|c|c|c|c|c|c|c|c|c|}
\hline \multirow{2}{*}{ Isolated } & \multicolumn{14}{|c|}{ Antibiotics } \\
\hline & AMP & AZI & CIP & CLI & CLO & ERI & GEN & LNZ & OXA & PEN & RIF & SUT & TET & VAN \\
\hline Streptococcus spp. & $\mathrm{NA}^{*}$ & $\begin{array}{l}48,1 \% \\
(26 / 54) \\
\end{array}$ & NA* & $\begin{array}{l}\mathbf{7 5 , 9 \%} \\
(41 / 54) \\
\end{array}$ & $\begin{array}{r}9,2 \% \\
(5 / 54) \\
\end{array}$ & $\begin{array}{l}38,9 \% \\
(21 / 54) \\
\end{array}$ & NA* & $\begin{array}{l}7,4 \% \\
(4 / 54) \\
\end{array}$ & NA* & $\begin{array}{l}\mathbf{7 7 , 7 \%} \\
(42 / 54) \\
\end{array}$ & NA* & NA* & $\begin{array}{l}29,6 \% \\
(16 / 54) \\
\end{array}$ & $\begin{array}{r}9,2 \% \\
(5 / 54) \\
\end{array}$ \\
\hline Enterococcus spp. & $\begin{array}{c}0 \% \\
(0 / 5) \\
\end{array}$ & NA* & $\begin{array}{c}20,0 \% \\
(1 / 5) \\
\end{array}$ & NA* & $\begin{array}{c}0 \% \\
(0 / 5) \\
\end{array}$ & $\begin{array}{l}40 \% \\
(2 / 5) \\
\end{array}$ & NA* & $\begin{array}{c}0 \% \\
(0 / 5) \\
\end{array}$ & NA* & $\begin{array}{c}20,0 \% \\
(1 / 5) \\
\end{array}$ & NA* & NA* & $\begin{array}{c}60,0 \% \\
(3 / 5) \\
\end{array}$ & $\begin{array}{c}0 \% \\
(0 / 5) \\
\end{array}$ \\
\hline $\begin{array}{l}\text { Staphylococcus } \\
\text { spp. }\end{array}$ & NA* & $\begin{array}{l}66,7 \% \\
(6 / 9)\end{array}$ & $\begin{array}{c}55,6 \% \\
(5 / 9)\end{array}$ & $\begin{array}{c}\mathbf{7 7 , 8 \%} \\
(7 / 9) \\
\end{array}$ & $\begin{array}{c}55,6 \% \\
(5 / 9)\end{array}$ & $\begin{array}{c}66,7 \% \\
(6 / 9)\end{array}$ & $\begin{array}{c}55,6 \% \\
(5 / 9)\end{array}$ & $\begin{array}{c}55,6 \% \\
(5 / 9)\end{array}$ & $\begin{array}{c}\mathbf{8 8 , 9 \%} \\
(8 / 9) \\
\end{array}$ & $\begin{array}{l}66,7 \% \\
(6 / 9)\end{array}$ & $\begin{array}{c}55,6 \% \\
(5 / 9)\end{array}$ & $\begin{array}{c}66,7 \% \\
(6 / 9) \\
\end{array}$ & $\begin{array}{c}55,6 \% \\
(5 / 9)\end{array}$ & NA* \\
\hline Bacillus spp. & NA* & $\begin{array}{c}14,3 \% \\
(1 / 7)\end{array}$ & $\begin{array}{c}14,3 \% \\
(1 / 7)\end{array}$ & $\begin{array}{c}\mathbf{8 5 , 7 \%} \\
(6 / 7)\end{array}$ & $\begin{array}{c}14,3 \% \\
(1 / 7)\end{array}$ & $\begin{array}{c}0 \% \\
(0 / 7)\end{array}$ & $\begin{array}{c}14,3 \% \\
(1 / 7)\end{array}$ & $\begin{array}{c}14,3 \% \\
(1 / 7)\end{array}$ & $\begin{array}{c}\mathbf{1 0 0 , 0 \%} \\
(7 / 7)\end{array}$ & $\begin{array}{c}100,0 \% \\
(7 / 7)\end{array}$ & $\begin{array}{c}\mathbf{8 5 , 7 \%} \\
(6 / 7)\end{array}$ & $\begin{array}{c}100,0 \% \\
(7 / 7)\end{array}$ & $\begin{array}{c}28,6 \% \\
(2 / 7)\end{array}$ & NA* \\
\hline
\end{tabular}

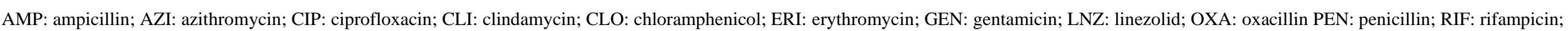
SUT: sulfazotrim; TET: tetracycline; VAN: vancomycin. NA* (Antibiotic not analyzed). Source: Authors.

In Table 2. there is high resistance among the isolated strains, highlighting, it should be noted that the strains that presented the highest means among the percentages of

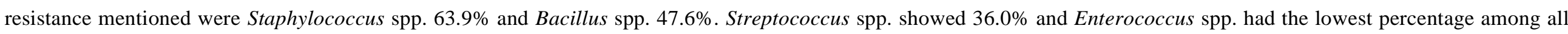
with $17.5 \%$.

The percentual MDR results, were from Bacillus spp. 100\% (7/7), Staphylococcus spp. 77.8\% (7/9), Streptococcus spp. 48.1\% (26/54) and Enterococcus spp. 0\% (0/5). Staphylococcus spp. they were the only bacteria that presented PDR, showing 55.6\% (5/7).

The association/correlation among all sample data, collection, point, culture medium and antibiotic resistance/sensitivities found was verified, these are described in Table 3. 
Table 3. Spearman correlation among antibiotics, medium, point, sample and collection of the Meia Ponte river, Goiás State, Brazil.

\begin{tabular}{|c|c|c|c|c|c|c|c|c|c|c|c|c|c|c|c|c|c|c|}
\hline & STRAINS & AZI & CIP & CLI & CLO & ERI & GEN & OXA & LNZ & PEN & RIF & SUT & TET & VAN & Medium & Point & Sample & Collection \\
\hline STRAINS & 0.00 & & & & & & & & & & & & & & & & & \\
\hline AZI & 0.06 & 1.00 & & & & & & & & & & & & & & & & \\
\hline CIP & 0.11 & 0.07 & 1.00 & & & & & & & & & & & & & & & \\
\hline CLI & 0.18 & 0.05 & -0.13 & 1.00 & & & & & & & & & & & & & & \\
\hline CLO & 0.04 & $-0.36^{*}$ & -0.04 & 0.00 & 1.00 & & & & & & & & & & & & & \\
\hline ERI & 0.14 & 0.15 & $0.56^{*}$ & -0.07 & -0.16 & 1.00 & & & & & & & & & & & & \\
\hline GEN & $0.52 *$ & 0.40 & $0.53 *$ & -0.41 & $-0.53 *$ & 0.32 & 1.00 & & & & & & & & & & & \\
\hline OXA & -0.03 & 0.29 & -0.20 & -0.12 & 0.20 & 0.25 & -0.22 & 1.00 & & & & & & & & & & \\
\hline LNZ & -0.11 & $0.37 *$ & 0.07 & -0.23 & $-0.43^{*}$ & 0.11 & $0.76^{*}$ & -0.20 & 1.00 & & & & & & & & & \\
\hline PEN & -0.16 & $-0.36^{*}$ & -0.09 & 0.13 & 0.13 & 0.00 & -0.42 & $0.54 *$ & $-0.24 *$ & 1.00 & & & & & & & & \\
\hline RIF & 0.01 & -0.05 & $-0.52 *$ & $0.71 *$ & $0.52 *$ & 0.03 & $-0.58 *$ & 0.38 & $-0.52 *$ & $0.71 *$ & 1.00 & & & & & & & \\
\hline SUT & 0.12 & -0.10 & -0.37 & 0.23 & 0.37 & 0.32 & -0.42 & $0.54 *$ & -0.37 & $0.59 *$ & 0.71 & 1.00 & & & & & & \\
\hline TET & 0.10 & 0.05 & -0.09 & $0.37 *$ & 0.15 & 0.01 & -0.40 & 0.23 & -0.17 & -0.10 & 0.59 & 0.42 & 1.00 & & & & & \\
\hline VAN & 0.06 & 0.03 & -0.16 & 0.11 & -0.02 & -0.10 & - & - & $0.57^{*}$ & -0.02 & - & - & 0.02 & 1.00 & & & & \\
\hline Medium & -0.03 & 0.20 & $0.28^{*}$ & 0.18 & $-0.30 *$ & 0.17 & $0.50^{*}$ & -0.45 & $0.36^{*}$ & $-0.28 *$ & -0.54 & -0.46 & 0.14 & 0.19 & 1.00 & & & \\
\hline Point & 0.15 & 0.20 & 0.04 & -0.16 & -0.08 & 0.08 & $0.53^{*}$ & -0.41 & $0.36^{*}$ & -0.22 & -0.06 & -0.16 & 0.03 & 0.01 & 0.08 & 1.00 & & \\
\hline Sample & 0.22 & $0.26 *$ & 0.19 & 0.17 & 0.05 & $0.23 *$ & -0.08 & -0.17 & -0.02 & -0.12 & 0.42 & 0.02 & 0.17 & 0.17 & -0.08 & 0.19 & 1.00 & \\
\hline Collection & 0.06 & -0.06 & $-0.29 *$ & 0.02 & $-0.29 *$ & -0.05 & 0.33 & 0.17 & 0.14 & 0.08 & 0.16 & 0.32 & $-0.28 *$ & -0.15 & -0.05 & 0.07 & -0.21 & 1.00 \\
\hline
\end{tabular}

AMP was removed as it was only tested for Enterococcus spp. is all were sensitive, with no statistical variation. *; p < 0.05 . Source: Authors. 
In Table 3. some data were extremely important for the research, for example, when comparing antibiotics and stitches, and also among samples and antibiotics.

Data only within each bacterial species were also listed. For Bacillus spp. only a significant correlation $(\mathrm{p}<0.05)$ of 0.87 among point and GEN was found. For Enterococcus spp. a significant correction ( $<<0.05)$ was found among sample and CIP with 0.97 and among ERI and TET with 0.91. For Streptococcus spp. 12 significant correlations $(\mathrm{p}<0.05)$ were obtained, with emphasis between ERI with AZI of 0.64 and VAN and LNZ of 0.57. For Staphylococcus spp. 34 significant correlations were obtained $(\mathrm{p}<0.05)$ with emphasis among ERI with AZI of 0.98, AZI with CIP, CLO, GEN, LNZ, RIF and TET of -0.79.

\section{Discussions}

The water temperature investigation process serves as a quality parameter, and the increase in temperature is associated with pollutants and proliferation of microorganisms in the aquatic environment (WHO, 2017). In addition, the occurrence of temperature changes among the dry and rainy seasons may be associated with the flow of waste in the water brought in by the rains (Adesakin et al., 2020).

On the media chosen for isolation, it was observed (Table 1), in general, the highest bacterial count for sediment samples when compared to raw water samples. This increased amount of strains found in the sediment reports a bacterial accumulation, demonstrating that the flow of sediment into the water body can generate an increase in the amount of fecal and bacterial contamination (Pandey et al., 2018).

There was more CFU in the culture media in the rainy season when compared to the dry season, occurring due to the fact that in the rainy season the runoff brings animal feces, pollutants and soil contaminants to rivers and lakes, multiplying the amount of these microorganisms in the water (Chen et al., 2017).

The work published in 2017 (Gomes et al., 2017), also performed analyzes in the water in the same aquatic environment of the present study, collections carried out in 2015/2016 and in periods of rain and drought, found Bacillus spp. $13.6 \%$ (14/103) and Enterococcus spp. 20.4\% (21/103). Comparing the previous data with the present work, it is a smaller number of the total of isolates, however, many strains of Streptococcus spp. were isolated and in the study in 2017 the bacterium was not found. The explanation for this distinction is because the cited authors (Gomes et al., 2017), used a no specific culture media and in this current research has chosen to use specific culture media for gram-positive bacteria.

Another study carried out in the Apies River in South Africa showed an increase in the quantification of Enterococcus spp. in sediment samples using specific isolation medium for this bacterium, the indication of this change being the association with the accumulation of fecal bacteria in the sediment, where this location is described as a "protection" for these microorganisms (Ekwanzala et al., 2017).

Researchers (Semedo-Lemsaddek et al., 2018), investigated the resistance of Enterococcus spp. in water samples from Portugal (Companhia das Lezírias) and Brazil (Rio Paranapanema) using specific culture medium to identify this bacterial genus. It was observed that Enterococcus spp. isolates from Brazil are more resistant when compared to isolates from Portugal, mainly to CLI, Enrofloxacin and VAN antibiotics. However, in the study carried out in the Meia Ponte River, Enterococcus spp. tested, showed higher resistance to ERI and TET, with different resistance results when comparing the two studies.

There was a survey conducted in Nigeria (Onuoha, 2017), finding 5.6\% (1/18) of Streptococcus spp. bacteria isolated from this region. It was found that this isolated strain was resistant to ERI and Streptomycin, and in this study, Streptococcus spp. identified showed higher resistance to the antimicrobials PEN, CLI, AZI and ERI, respectively, resembling the resistance to ERI for this particular bacterium in the two studies cited.

A survey in Limpopo, South Africa using water and sediment samples, demonstrated that 37 of the resistant isolates of the Bacillaceae family were isolated from water samples, even so, these bacteria showed higher resistance to the 
antimicrobial ceftriaxone and no resistance to OXA, PEN and SUT. Being totally divergent results of resistance profile when compared to Bacillus spp. described in table 2 (Jardine et al., 2019).

Another study in Dhaka, Bangladesh with mineral water samples analyzed in different climatic seasons found resistance of Staphylococcus spp. During the study, there is an association among the resistance to cefixime of these bacteria and the access of this microorganism with the population, warning of contamination by Staphylococcus spp. in water accessible to the population, consolidating the importance of inspection and research to assess these resistant microorganisms (Aditi et al., 2017).

According to the authors (Kaur et al., 2020), in hospital wastewater, the presence of strains of Bacillus spp., Staphylococcus spp. and Streptococcus spp. with high resistance because it is an environment with high concentrations of drugs, radioactive products, among others. The authors mention that Staphylococcus spp. it is the one with the greatest resistance and even multiple resistances. Comparing with the study carried out in the Meia Ponte River, the results showed that Staphylococcus spp. showed greater resistance among other microorganisms found at the site, so it is possible to compare the resistance of bacteria found in hospital wastewater.

In 2019, a survey of strains with MDR, collecting samples from the surfaces of a hospital in Morocco, found strains of Staphylococcus aureus with MDR, being a suitable place to show high resistance, however, the Meia Ponte River also presented an alarming number of MDR in Staphylococcus spp. being worrying results (Chaoui et al., 2019). In turn, other researchers (Palacios et al., 2017) found Bacillus spp. MDR in Chihuahua, Mexico, in soil samples irrigated with untreated water; the author argues that this high resistance.

Phenotypic results of MDR presented by some isolated bacteria are being related to findings of high doses of antibiotics found in sewage of a hospital in São Paulo - Brazil. This disposal found in sewers may be related to the exacerbated use of antibiotics in hospitals, because it is an environment with a patient with several and distinct infections, thus influencing the spread of bacterial resistance (Brito et al., 2020; Carvalho et al., 2021).

The strong association in the antibiotic-antibiotic correlation is characterized by being of similar antimicrobial classes (El-Din et al., 2021), being ERI and AZI, for example, belonging to the class of macrolides that have the function of preventing the protein synthesis of the bacteria (Munita \& Arias, 2016). The author (Olivas, 2013), explains that $S$. aureus has resistance to the efflux pump and this can generate multiple resistances to antimicrobials, such as: TET, CIP, GEN, PEN, among others; may explain these various correlations arising from Staphylococcus spp. presented in the statistics.

\section{Conclusion}

The presence of gram-positive bacteria with resistance in the Meia Ponte River was already expected because it is a place with several different bacterial strains (animal and human), in addition to the presence of pollution and sewage disposal at the site, however, the results found for MDR and even PDR were alarming for being a water resource used by countless individuals in the state of Goiás.

Still, it is necessary to collect more data on the spot and carry out research /tests, such as genotyping to find possible resistance genes in the isolated bacteria and comparing with the phenotypic resistance found. With these data collected in this research, it can serve to alert the population that uses this water and raise awareness about possible problems with infections caused by these resistant bacteria.

\section{References}

Adesakin, T. A., Oyewale, A. T., Bayero, U., Mohammed, A. N., Aduwo, I. A., Ahmed, P. Z., Abubakar, N. D., \&Barje, I. B. (2020). Assessment of bacteriological quality and physico-chemical parameters of domestic water sources in Samaru community, Zaria, Northwest Nigeria. Heliyon, 6(8), 1-13. https://doi.org/10.1016/j.heliyon.2020.e04773 
Amarasiri, M., Sano, D., \& Suzuki, S. (2019). Understanding human health risks caused by antibiotic resistant bacteria (ARB) and antibiotic resistance genes (ARG) in water environments: Current knowledge and questions to be answered. Crit Rev Sci Environ Technol, 50(19), 2016-2059. https://doi.org/10.1080/10643389.2019.1692611

ANVISA. (2005). Performance Standards for Testing Antimicrobial Sensitivity: 15th Information Supplement (2005). Agência Nacional de Vigilância Sanitária, Brazil (ANVISA), $25 n^{\circ} 1,1-177$.

ANVISA. (2013). Manual de Microbiologia Clínica para o Controle de Infecções Relacionadas à Assistência à Saúde. Módulo 6: Detecção e identificação e bactérias de importância médica. Agência Nacional de Vigilância Sanitária, Brazil (ANVISA), 6, 1-93.

APHA. (2017). Standard Methods for the examination of water and wastewater - Twenty Third Edition. American Public Health Association (APHA), 23, 11546.

Asma, R., Alam, Md. J., Rahimgir, M., Asaduzzaman, M., Islam, A. M., Uddin, N., Khan, Md. S. I., Jahan, N.-W.-B., Siddika, S. S., \& Datta, S. (2019). Prevalence of Multidrug-Resistant, Extensively Drug-Resistantand Pandrug-Resistant Uropathogens Isolated From UrinaryTract Infection Cases in Dhaka, Bangladesh. Avicenna J Clin Microbiol Infect, 6(2), 44-48. https://doi.org/10.34172/ajcmi.2019.09

Bailão, E. F. L. Cardoso., Zago, L. M. Sousa., Silva, N. C., Machado, K. B., D’Abadia, P. L., Oliveira, P. H. F., Nabout, J. C., \& Almeida, L. M. (2020). Urban occupation increases water toxicity of an important river in central Brazil. J Soc Technol Environ Sci - Fronteiras, 9(1), 73-86. https://doi.org/10.21664/2238-8869.2020v9i1.p73-86

Brandão, C. Jesus., Botelho, M. J. Coelho., Sato, M. I. Zanoli., \& Lamparelli, M. C. (2011). Guia Nacional De coleta e Preservação De amostras: Água, Sedimento, Comunidades Aquáticas E Efluentes Líquidos. Companhia Ambiental Do Estado de São Paulo (CETESB), $2,326$. Accessed 14 Jul 2021.

Brito, C. B. S., Correia, K. G., Bezerra, J. L., Sousa, J. C., Andrade, S. M., Cunha, M. A., Taminato, R. L., \& Oliveira, E. H. (2020). O uso de antibióticos e sua relação com as bactérias multirresistentes em hospitais. Research, Society and Development, 9(11), 1-12. https://doi.org/10.33448/rsd-v9i11.9852

Carvalho, J. J. V. de, Boaventura, F. G., Silva, A. de C. R. da, Ximenes, R. L., Rodrigues, L. K. C., Nunes, D. A. de A., \& Souza, V. K. G. de. (2021). Bactérias multirresistentes e seus impactos na saúde pública: Uma responsabilidade social. Research, Society and Development, 10(6), 1-11. https://doi.org/10.33448/rsd-v10i6.16303

Chaoui, L., Mhand, R., Mellouki, F., \& Rhallabi, N. (2019). Contamination of the Surfaces of a Health Care Environment by Multidrug-Resistant (MDR) Bacteria. Inter J Microbiol, 2019. https://doi.org/10.1155/2019/3236526

Chen, Z., Yu, D., He, S., Ye, H., Zhang, L., Wen, Y., Zhang, W., Shu, L., \& Chen, S. (2017). Prevalence of Antibiotic-Resistant Escherichia coli in Drinking Water Sources in Hangzhou City. Front Microbiol, O(JUN), 1133. https://doi.org/10.3389/fmicb.2017.01133

CLSI. (2019). Performance Standards for Antimicrobial Susceptibility Testing, 29th Edition. In Clinical Laboratory Standards Institute (CLSI) (pp. 1-320).

Coelho, F. R., Rubin, J. C. R., \& Silva, A. M. T. C. (2021). Análise de Qualidade da Água no Alto Curso do Rio Meia Ponte Entre 2013 e 2018. Revista EVS Revista de Ciências Ambientais e Saúde, 47(1), 1-9.

Dang, B., Mao, D., Xu, Y., \& Luo, Y. (2017). Conjugative multi-resistant plasmids in Haihe River and their impacts on the abundance and spatial distribution of antibiotic resistance genes. Water Res, 111, 81-91. https://doi.org/10.1016/j.watres.2016.12.046

Ekwanzala, M. D., Abia, A. L. K., Ubomba-Jaswa, E., Keshri, J., \& Momba, N. B. M. (2017). Genetic relatedness of faecal coliforms and enterococci bacteria isolated from water and sediments of the Apies River, Gauteng, South Africa. AMB Express, 7(1), 20. https://doi.org/10.1186/s13568-016-0319-4

El-Din, H. T. Nour., Yassin, A. S., Ragab, Y. M., \& Hashem, A. M. (2021). Phenotype-Genotype Characterization and Antibiotic-Resistance Correlations Among Colonizing and Infectious Methicillin-Resistant Staphylococcus aureus Recovered from Intensive Care Units. Infection and Drug Resistance, 14, 1557-1571. https://doi.org/10.2147/IDR.S296000

Gogoi, A., Mazumder, P., Tyagi, V. K., Chaminda, T. G. G., An, A. K., \& Kumar, M. (2018). Occurrence and fate of emerging contaminants in water environment: A review. Groundwater for Sustainable Development, 6, 169-180. https://doi.org/10.1016/J.GSD.2017.12.009

Gomes, R. Pereira., Rodrigues, A. Alves., Pincerati, M. Regina., Barbosa, M. Santiago., Braga, C. A. S. Bitencourt., Gonçalves, J. D. Vieira., \& Carneiro, L. Carla. (2017). Assessment of the Bacteriological Quality of the Raw Water and the Antimicrobial Susceptibility Profile of Bacteria Isolated in Water Surface of a River. Inter J Microbiol Res, 9(9), 949-953.

Jardine, J., Mavumengwana, V., \& Ubomba-Jaswa, E. (2019). Antibiotic resistance and heavy metal tolerance in cultured bacteria from hot springs as indicators of environmental intrinsic resistance and tolerance levels. Envir Pollut (Barking, Essex: 1987), 249, 696-702. https://doi.org/10.1016/j.envpol.2019.03.059

Karkman, A., Do, T. T., Walsh, F., \& Virta, M. P. (2018). Antibiotic-Resistance Genes in Waste Water. Trends Microbiol, 26(3), 220-228. https://doi.org/10.1016/j.tim.2017.09.005

Kaur, R., Yadav, B., \& Tyagi, R. D. (2020). Microbiology of hospital wastewater. Curr Dev Biotechnol and Bioengineering, 103-148. https://doi.org/10.1016/B978-0-12-819722-6.00004-3

Köche, J. C. (2016). Fundamentos de metodologia científica. Editora Vozes.

Maruzani, R., Pathak, A., Ward, M., Serafim, V., Munoz, L. P., Shah, A. J., \& Marvasi, M. (2020). Antibiotic selective pressure in microcosms: Pollution influences the persistence of multidrug resistant Shigella flexneri 2a YSH6000 strain in polluted river water samples. Environ Technol Innov, 19. https://doi.org/10.1016/j.eti.2020.100821

Mohapatra, D. P., \& Kirpalani, D. M. (2019). Advancement in treatment of wastewater: Fate of emerging contaminants. The Canadian J Chem Eng, 97(10), 2621-2631. https://doi.org/10.1002/cjce.23533 
Munita, J. M., \& Arias, C. A. (2016). Mechanisms of Antibiotic Resistance. Microbiol Spectr, 4(2), 464-472. https://doi.org/10.1128/microbiolspec.VMBF0016-2015

OEHHA (Office of Environmental Health Hazard Assessment). (2020). Toxicity criteria on chemicals evaluated by OEHHA.https://oehha.ca.gov/chemicals. Pereira, A. S., Shitsuka, D. M., Parreira, F. J., \& Shitsuka, R. (2018). Metodologia da pesquisa científica. [e-book].

Olivas, C. (2013). Trends In Antibiotic Resistance And Correlations Of Antibiotic Use And Antibiotic Resistance In A Small Hospital In E1 Paso, Texas 20132015. Open Access Theses \& Dissertations. University of Texas at El Paso, 1-42. Acessed 24 Jul 2021.

Onuoha, S. C. (2017). Isolation and Characterization of Multi-drug Resistant Bacterial Species from Selected Water Sources in Izzi Area, Southeastern Nigeria. World Appl Sci J, 35(1), 27-32. https://doi.org/10.5829/idosi.wasj.2017.27.32

Palacios, O. A., Contreras, C. A., Muñoz-Castellanos, L. N., González-Rangel, M. O., Rubio-Arias, H., Palacios-Espinosa, A., \& Nevárez-Moorillón, G. V. (2017). Monitoring of indicator and multidrug resistant bacteria in agricultural soils under different irrigation patterns. Agric Water Manag, 184, 19-27. https://doi.org/0.1016/j.agwat.2017.01.001

Pandey, P., Soupir, ML., Wang, Y., Cao, W., Biswas, S., Vaddella, V., Atwill, R., Merwade, V., \& Pasternack, G. (2018). Water and Sediment Microbial Quality of Mountain and Agricultural Streams. J Environ Qual, 47(5), 985-996. https://doi.org/10.2134/jeq2017.12.0483

Rahmani, F., Hmaied, F., Matei, I., Chirila, F., Fit, N., Yahya, M., Jebri, S., Amairia, S., \& Hamdi, M. (2020). Occurrence of Staphylococcus spp. and investigation of fecal and animal viral contaminations in livestock, river water, and sewage from Tunisia and Romania. Environ Monit Assess, 192(4), 1-12. https://doi.org/10.1007/s10661-020-8172-y

Ruiz-Aguirre, A., Polo-López, M. I. ;, Fernández-Ibáñez, P., \& G., Z. (2017). Integration of Membrane Distillation with solar photo-Fenton for purification of water contaminated with Bacillus sp. and Clostridium sp. spores. Sci Total Environ, 595, 110-118. https://doi.org/10.1016/j.scitotenv.2017.03.238

Semedo-Lemsaddek, T., Pedroso, N. M., Freire, D., Nunes, T., Tavares, L., Verdade, L. M., \& Oliveira, M. (2018). Otter fecal enterococci as general indicators of antimicrobial resistance dissemination in aquatic environments. Ecol Indicators, 85, 1113-1120. https://doi.org/10.1016/j.ecolind.2017.11.029

Shao, S., Hu, Y., Cheng, J., \& Chen, Y. (2018). Research progress on distribution, migration, transformation of antibiotics and antibiotic resistance genes (ARGs) in aquatic environment. Crit Rev Biotechnol, 38(8), 1195-1208. https://doi.org/10.1080/07388551.2018.1471038

Sobisch, L.-Y., Rogowski, K. M., Fuchs, J., Schmieder, W., Vaishampayan, A., Oles, P., Novikova, N., \& Grohmann, E. (2019). Biofilm Forming Antibiotic Resistant Gram-Positive Pathogens Isolated From Surfaces on the International Space Station. Front Microbiol, 10, 1-16. https://doi.org/10.3389/fmicb.2019.00543

StatSoft I. (2012). STATISTICA StatSoft I. (2012). Version 7. 2004. Tulsa, USA, 150. Acess 24 Jul 2021. https://www.scirp.org/(S(351jm bntvnsjt1 aadkposzje))/reference/ReferencesPapers.aspx?ReferenceID=410046

Wang, Q., Liu, L., Hou, Z., Wang, L., Ma, D., Yang, G., Guo, S., Luo, J., Qi, L., \& Luo, Y. (2020). Heavy metal copper accelerates the conjugative transfer of antibiotic resistance genes in freshwater microcosms. Sci Total Environ, 717. https://doi.org/10.1016/j.scitotenv.2020.137055

WHO. (2017). Guidelines for drinking-water quality, 4th edition, incorporating the 1st addendum. World Health Organization (WHO), 1-631.

Yusuf, U., Kotwal, S. K., Gupta, S., \& Ahmed, T. (2018). Identification and antibiogram pattern of Bacillus cereus from the milk and milk products in and around Jammu region. Vet World, 11(2), 186-191. https://doi.org/10.14202/vetworld.2018.186-191

Zhang, Y., Feng, R., Li, L., Zhou, X., Li, Z., Jia, R., Song, X., Zou, Y., Yin, L., He, C., Liang, X., Zhou, W., Wei, Q., Du, Y., Yan, K., Wu, Z., \& Yin, Z. (2018). The Antibacterial Mechanism of Terpinen-4-ol Against Streptococcus agalactiae. Curr Microbiol, 75(9), 1214-1220. https://doi.org/10.1007/s00284018-1512-2 